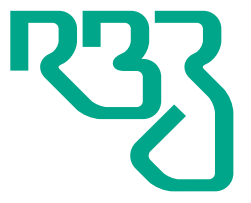

Revista Brasileira de Zootecnia

Brazilian Journal of Animal Science ISSN 1806-9290

www.rbz.org.br

\section{Blood parameters of Angus and Nellore young bulls fed diets with or without forage}

\author{
Luciana Navajas Rennó ${ }^{1}$ (iD), Rafael Aparecido Gomes ${ }^{2 *}$ (iD), Taiane da Silva \\ Martins $^{1}$ (iD, Karina Costa Busato ${ }^{1}$ (iD), Marcio Machado Ladeira ${ }^{3}$ (iD, Maria \\ Helena de Oliveira $^{3}$ (iD, Jarbas Miguel da Silva Júnior ${ }^{1}$ (iD), Mario Luiz \\ Chizzotti $^{1}$ iD \\ ${ }^{1}$ Universidade Federal de Viçosa, Departamento de Zootecnia, Viçosa, MG, Brasil. \\ ${ }^{2}$ Instituto Federal de Educação, Ciência e Tecnologia do Pará, Campus Castanhal, Castanhal, \\ PA, Brasil. \\ ${ }^{3}$ Universidade Federal de Lavras, Departamento de Zootecnia, Lavras, MG, Brasil.
}

*Corresponding author:
rafaelzoo84@yahoo.com.br

Received: December 3, 2018

Accepted: July 14, 2019

How to cite: Rennó, L. N.; Gomes, R. A.; Martins, T. S.; Busato, K. C.; Ladeira, M. M.; Oliveira, M. H.; Silva Júnior, J. M. and Chizzotti, M. L. 2019. Blood parameters of Angus and Nellore young bulls fed diets with or without forage. Revista Brasileira de Zootecnia 48:e20180172. https://doi.org/10.1590/rbz4820180172

Copyright: This is an open access article distributed under the terms of the Creative Commons Attribution License (http://creativecommons.org/licenses/by/4.0/), which permits unrestricted use, distribution, and reproduction in any medium, provided the original work is properly cited.

\begin{abstract}
We evaluated blood parameters of Angus and Nellore bulls fed diets with and without forage. Forty animals with initial body weight (BW) of $380 \pm 16.2 \mathrm{~kg}$ were housed in individual stalls. Eight bulls of each breed were fed a whole shelled corn (WSC) $\operatorname{diet}$ [ $850 \mathrm{~g} \mathrm{~kg}^{-1}$ of WCS and $150 \mathrm{~g} \mathrm{~kg}^{-1}$ of a pellet based on soybean meal, dry mater (DM) basis] or a ground corn with silage (GC) diet (300 g kg-1 of silage and $700 \mathrm{~g} \mathrm{~kg}^{-1}$ of a concentrate based on corn and soybean meal, DM basis), ad libitum, and four animals of each breed were limited-fed the GC diet [feed restriction (FR), 55\% of the DM intake of bulls fed ad libitum, adjusted for the metabolic BW]. Intake was measured daily, and a metabolism trial was conducted with total collection of feces and urine to estimate the ruminally degraded and undegraded protein (intake and nitrogen balance). Blood samples for determination of hormones and metabolites were collected. The data were analyzed using the GLM procedure of SAS adopting a significance level of 0.05. The diet affected only the serum concentrations of triglycerides, HDL, and VLDL, with limitedfed animals presenting smaller concentrations than ad libitum-fed bulls. No difference in blood parameters was observed between animals fed WSC or GC diets. Nellore bulls presented greater T4, cholesterol, HDL, LDL, and serum urea nitrogen concentrations than Angus. Feeding finishing beef cattle with no-roughage diets does not alter their blood parameters. Also, our results support that Zebu cattle might have lower serum removal of nutrients due to a lesser demand for fat and protein deposition than Bos taurus taurus.
\end{abstract}

Keywords: blood metabolites, Bos taurus indicus, Bos taurus taurus, feed restriction, hormones

\title{
Introdution
}

Bos taurus indicus, commonly used in tropical livestock, share a common ancestor with Bos taurus taurus (Loftus et al., 1994). However, both subspecies have undergone separate evolution for thousands of years, and during this period, Zebu cattle breeds have been exposed to harsh environments, resulting in acquired adaptations to survive, adapting to hot and humid weather and poor-quality diets (Turner, 1980).

Diets with whole shelled corn (WSC) without forage have been used in the United States since 1970. Depending on corn prices and availability, feeding cattle for fattening with no-forage diets can be cheaper, since roughage production requires large areas and specific and expensive agricultural 
equipment. Furthermore, comparing with forage, grains are higher energy-dense and easier to transport and stock. In South America, the use of WSC diets is more recent, but it has been increasing in the last years. Previous studies have shown that animals fed WSC diets are more efficient (Traxler et al., 1995; Turgeon et al., 2010). However, most of the studies on WSC diets used taurine cattle, and only a few were carried out using Bos taurus indicus. Besides, when fed concentrate-based diets, Bos taurus taurus have greater intake relative to their maintenance requirements and higher average daily gain than Zebu cattle (Krehbiel et al., 2000; Carvalho et al., 2016). On the other hand, Bos taurus indicus utilize low-quality forage diets more efficiently than taurine cattle (Krehbiel et al., 2000).

Blood metabolites are a useful indicator of the metabolic status of animals and can be used to predict nutrient utilization. Most of the studies on high-grain diets has focused only on animal production, evaluating weight gain, feed efficiency, and carcass characteristics, but not on indicators of metabolic status, and to the best of our knowledge, other studies have not analyzed blood metabolites in cattle fed WSC diets. We hypothesize that serum parameters are different between animals fed or not forage and that the magnitude of the changes are different between Angus and Nellore bulls. Therefore, the objective of this work was to compare blood parameters of finishing Angus and Nellore bulls fed either a WSC diet or a ground corn with silage diet on an ad libitum or restricted basis.

\section{Material and Methods}

All animal care and use procedures were evaluated and approved by the Bioethic Committee in Utilization of Animals, case no. 048/2012. The study was conducted in Lavras (Minas Gerais, Brazil), located at $21^{\circ} 14^{\prime}$ South latitude, $45^{\circ} 00^{\prime}$ West longitude, and at an altitude of $918 \mathrm{~m}$. During the experimental period, the average temperature was $23^{\circ} \mathrm{C}$, the maximum temperature was $36^{\circ} \mathrm{C}$, the minimum temperature was $20^{\circ} \mathrm{C}$, and the average relative humidity was $75 \%$.

The animals were housed outdoors in individual covered pens measuring $1 \times 5 \mathrm{~m}$, with concreted floor. The cover was enough to provide shade to the animals and to the feed and water troughs.

Forty bulls were used (20 Nellore and 20 Angus) with an initial body weight (BW) of $380( \pm 16.2) \mathrm{kg}$. Animals were fed the same diet (ground corn with corn silage - GC), ad libitum, for $28 \mathrm{~d}$ before the beginning of the experiment. Then, eight animals of each breed were fed a WSC diet or the GC diet on an ad libitum basis (Table 1), and four animals of each breed were limited-fed the GC diet (feed restriction - FR, $55 \%$ of the DM intake of ad libitum-fed bulls, adjusted for the metabolic BW). The GC diet was formulated according to NRC (2000) for an average daily gain of $1.4 \mathrm{~kg} \mathrm{~d}^{-1}$. The animals were individually fed two times a day, at 07.30 and $15.30 \mathrm{~h}$. Feed and orts were weighed and sampled daily to quantify dry matter intake (DMI). Ingredients and orts samples were oven-dried at $55{ }^{\circ} \mathrm{C}$ for $72 \mathrm{~h}$. Animals fed ad libitum were offered enough feed to ensure about $5 \%$ of orts daily. The experimental period lasted for $84 \mathrm{~d}$ after the adaption period.

A digestion trial was conducted with all animals. Feed intake, feed refusals, feces, and urine were recorded daily during three days. Feces excreted were collected directly from the floor, immediately after the animal had defecated, and urine excreted was collected using a rubber funnel tied to the body of the animal and connected to a coitaner filled with $200 \mathrm{~mL}$ of $20 \% \mathrm{H}_{2} \mathrm{SO}_{4}$ by a drainage hose. Daily, a $10 \%$ sample of orts, feces, and urine was collected. The urine samples were stored at $-20^{\circ} \mathrm{C}$, and feces samples were immediately dried at $55^{\circ} \mathrm{C}$ for $72 \mathrm{~h}$.

Animals were slaughtered after $84 \mathrm{~d}$. Prior to the slaughter, bulls were feed-fasted for $12 \mathrm{~h}$. Then, they were desensitized with a non-penetrating stunner and harvested by exsanguination using conventional humane procedures. Blood samples for determination of hormones and metabolites were collected during the slaughter, immediately after exsanguination with vacuum tubes without anticoagulant and immediately centrifuged $(3000 \times \mathrm{g}, 15 \mathrm{~min})$. Serum was separated and stored at $-20^{\circ} \mathrm{C}$ until analysis.

The chemical analysis of the diet ingredients was described by Gomes et al. (2017). Ruminally undegraded protein (RUP) intake ( $\mathrm{g} \mathrm{kg}^{-1} \mathrm{~d}^{-1}$ of BW) was estimated following the NRC (2001) models. Values for digestion rate (kd) of protein fraction B and RUP digestibility of each feed ingredient were 
Table 1 - Ingredients and chemical composition of diets, in $\mathrm{g} \mathrm{kg}^{-1}$ of dry matter

\begin{tabular}{lcc}
\hline Item & GC diet & WSC diet \\
\hline Ingredient & & \\
Corn silage & 300 & - \\
Corn grain & 580 & 850 \\
Soybean meal & 100 & - \\
Mineral premix $^{1}$ & 20 & - \\
Pelleted suplement $^{2}$ & - & 150 \\
Chemical composition $^{3}$ & & \\
Dry matter $^{3}$ & 589 & 878 \\
Crude protein $_{\text {Protein fraction A }}$ & 117 & 136 \\
Protein fraction B & 27.1 & 45.2 \\
Protein fraction C & 87.4 & 87.9 \\
Neutral detergent fiber & 2.5 & 2.9 \\
Non-fibrous carbohydrates & 267 & 151 \\
Starch & 541 & 639 \\
Ether extract & 504 & 618 \\
Ash & 23.0 & 28.0 \\
Metabolizable energy & & 46.0 \\
\hline
\end{tabular}

${ }^{1}$ Assurance level per kilogram of product: calcium, 170 g; phosphorus, 31 g; sodium, 155 g; zinc, 2 mg; manganese, 515 mg; copper, 15 mg; iodine, $29 \mathrm{mg}$; selenium, $2.4 \mathrm{mg}$.

${ }^{2}$ Assurance level per kilogram of product: calcium, 45 g; phosphorus, 11 g; magnesium, 7.5 g; copper, 104 mg; zinc, 344 mg; selenium, 0.83 mg; virginiamycin, $140 \mathrm{mg}$; monensin, $120 \mathrm{mg}$.

${ }^{3}$ In $\mathrm{g} \mathrm{kg}^{-1}$ as fed.

${ }^{4} \mathrm{MJ} \mathrm{kg}^{-1}$ DM; Carvalho et al. (2016).

taken from NRC (2001) tables. It was assumed that the pellet had the same kd of protein fraction B and RUP digestibility as soybean meal. Ruminally degraded protein (RDP) intake $\left(\mathrm{g} \mathrm{kg}^{-1} \mathrm{~d}^{-1}\right.$ of BW) was calculated as the difference between crude protein intake $\left(\mathrm{g} \mathrm{kg}^{-1} \mathrm{~d}^{-1}\right.$ of BW) and RUP intake. Nitrogen balance (NB) was calculated as the difference between nitrogen intake $\left(\mathrm{g} \mathrm{kg}^{-1} \mathrm{~d}^{-1}\right.$ of BW) and nitrogen excreted in feces and urine $\left(\mathrm{g} \mathrm{kg}^{-1} \mathrm{~d}^{-1}\right.$ of BW).

Serum low-density lipoprotein (LDL) and very low-density lipoprotein (VLDL) were estimated following the method proposed by Friedewald et al. (1972). Bioclin/Quibasa (Minas Gerais, Brazil) kits were used to analyze the serum concentration of glucose (kit \#K082), total protein (kit \#K031), albumin (kit \#K040), urea (kit \#K056), triglycerides (kit \#K117), cholesterol (kit \#K083), and highdensity lipoprotein (HDL; kit \#K071), through an automatic biochemical analyzer (Mindray BS-200E; Shenzhen Mindray Bio-Medical Electronics Co., Ltd., Shenzhen, China). Insulin (kit \#2425-300A), total triiodothyronine (T3; kit\#125-300A), and total thyroxine (T4; kit \#225-300A) were analyzed by Enzyme Linked ImmunoSorbent Assay method through Monobind Inc. (California, United States) kits, using Biolisa Reader and Biolisa Washer (Bioclin/Quibasa, Minas Gerais, Brazil). Globulins were calculated by subtracting the albumin quantified from the total protein level. Serum urea nitrogen (SUN) was estimated as $46.67 \%$ of total serum urea.

Statistical analyses were performed using SAS (Statistical Analysis System, version 9.2). Data of performance, intake, nitrogen balance, and blood parameters were analyzed as completely randomized design in a factorial scheme (three diets $\times$ two breeds), using GLM procedures and considering animal as the experimental unit. The least squares means statement was used to calculate the adjusted means for treatments, and differences were considered statistically significant when $P \leq 0.05$; tendencies were discussed when $0.05<\mathrm{P} \leq 0.10$. The general mathematical model was represented by:

$$
\mathrm{Y}_{i j}=\mu+\mathrm{T}_{i}+\mathrm{M}_{j}+(\mathrm{TM})_{i j}+\varepsilon_{i j^{\prime}}
$$


in which $\mu$ is a constant, $T_{i}$ is the effect of breed, $M_{j}$ is the effect of diet, $(\mathrm{TM})_{i j}$ is the interaction between breed and diet, and $\varepsilon_{i j}$ is the residual random error.

\section{Results}

The initial BW was not different between breeds or diets (Table 2). However, Angus and Nellore bulls fed ad libitum performed better than limited-fed animals, with a final BW 19 and $7 \%$ greater $(\mathrm{P}<0.001)$ for Angus and Nellore, respectively, with no difference between WSC and GC diets. Angus bulls presented greater DM, average daily gain (ADG), RDP, and RUP intake and nitrogen balance (Table 2; $\mathrm{P}<0.001$ ) than Nellore. Angus bulls fed the GC diet presented greater RDP and RUP intake $(\mathrm{P}<0.001)$ than bulls fed the WSC diet. However, for Nellore cattle, only RDP was different between the two diets, with no difference in the RUP intake ( $\mathrm{P}=0.357)$. In addition, no difference was observed in the nitrogen balance between WSC and GC diets. The DMI, in $\mathrm{kg} \mathrm{d}^{-1}$, was not different $(\mathrm{P}>0.05)$ between Nellore bulls fed WSC or FR diets, while the animals fed GC and WSC diets had the same RUP intake.

There was no difference in the blood parameters of bulls fed WSC or GC diets. Limited-fed animals presented smaller serum concentrations of triglycerides, HDL, and VLDL ( $\mathrm{P} \leq 0.039)$ than ad libitum-fed bulls, and bulls fed the FR diet tended to have lower T3 concentration $(P=0.057)$ (Table 3). Nellore

Table 2 - Performance and intake of Angus and Nellore cattle fed diets with and without forage

\begin{tabular}{|c|c|c|c|c|c|c|c|c|c|c|}
\hline \multirow[b]{2}{*}{ Item } & \multicolumn{3}{|c|}{ Angus } & \multicolumn{3}{|c|}{ Nellore } & \multirow[b]{2}{*}{ SEM } & \multicolumn{3}{|c|}{ P-value } \\
\hline & GC & WSC & FR & GC & WSC & FR & & Breed & Diet & $\begin{array}{l}\text { Breed } \\
\times \text { diet }\end{array}$ \\
\hline Initial BW (kg) & 386 & 399 & 385 & 374 & 365 & 389 & 12.9 & 0.143 & 0.960 & 0.485 \\
\hline Final BW (kg) & $540 \mathrm{a}$ & $535 a$ & $454 \mathrm{~b}$ & $461 \mathrm{a}$ & $431 \mathrm{a}$ & $415 b$ & 17.1 & $<0.001$ & 0.004 & 0.225 \\
\hline Average daily gain $\left(\mathrm{kg} \mathrm{d}^{-1}\right)$ & $1.73 \mathrm{a}$ & $1.53 a$ & $0.86 \mathrm{~b}$ & $0.97 \mathrm{a}$ & $0.74 \mathrm{a}$ & $0.42 \mathrm{~b}$ & 0.15 & $<0.001$ & $<0.001$ & 0.572 \\
\hline Dry matter intake $\left(\mathrm{kg} \mathrm{d}^{-1}\right)$ & $13.7 \mathrm{~A}$ & $10.3 \mathrm{~B}$ & $6.5 \mathrm{C}$ & $9.7 \mathrm{~B}$ & $6.8 \mathrm{C}$ & $5.3 \mathrm{C}$ & 0.484 & $<0.001$ & $<0.001$ & 0.032 \\
\hline RDP intake ( $\mathrm{g} \mathrm{kg}^{-1} \mathrm{~d}^{-1}$ of $\left.\mathrm{BW}\right)$ & $1.79 \mathrm{a}$ & $1.66 \mathrm{~b}$ & $1.06 \mathrm{c}$ & $1.44 \mathrm{a}$ & $1.33 \mathrm{~b}$ & $0.93 \mathrm{c}$ & 0.109 & $<0.001$ & $<0.001$ & 0.146 \\
\hline RUP intake $\left(\mathrm{g} \mathrm{kg}^{-1} \mathrm{~d}^{-1}\right.$ of $\left.\mathrm{BW}\right)$ & $1.63 \mathrm{~A}$ & $1.37 \mathrm{~B}$ & $0.72 \mathrm{D}$ & $1.16 \mathrm{C}$ & $1.04 \mathrm{C}$ & $0.60 \mathrm{D}$ & 0.0546 & $<0.001$ & $<0.001$ & 0.048 \\
\hline Nitrogen balance $\left(\mathrm{g} \mathrm{kg}^{-1} \mathrm{~d}^{-1}\right.$ of BW) & $0.386 a$ & $0.376 \mathrm{a}$ & $0.174 \mathrm{~b}$ & $0.268 \mathrm{a}$ & $0.288 \mathrm{a}$ & $0.140 \mathrm{~b}$ & 0.0409 & $<0.001$ & $<0.001$ & 0.084 \\
\hline
\end{tabular}

GC - ground corn with silage diet; WSC - whole shelled corn diet; FR - feed restriction diet; BW - body weight; RDP - ruminally degraded protein; RUP - ruminally undegraded protein.

A,B,C,D - Different uppercase letters in the same row differ at $\mathrm{P}<0.05$ by least squares means for breed $\times$ diet effect.

a,b,c - Different lowercase letters in the same row, within diet, differ at $\mathrm{P}<0.05$ by least squares means.

Table 3 - Blood parameters of Angus and Nellore cattle fed diets with and without forage

\begin{tabular}{|c|c|c|c|c|c|c|c|c|c|c|}
\hline \multirow[b]{2}{*}{ Item } & \multicolumn{3}{|c|}{ Angus } & \multicolumn{3}{|c|}{ Nellore } & \multirow[b]{2}{*}{ SEM } & \multicolumn{3}{|c|}{ P-value } \\
\hline & GC & WSC & FR & GC & WSC & FR & & Breed & Diet & $\begin{array}{l}\text { Breed } \\
\times \text { diet }\end{array}$ \\
\hline Insulin $\left(\mu \mathrm{IU} \mathrm{mL} \mathrm{m}^{-1}\right)$ & 3.50 & 4.12 & 2.01 & 3.10 & 5.94 & 5.81 & 1.14 & 0.074 & 0.252 & 0.216 \\
\hline Glucose $\left(\mathrm{mg} \mathrm{dL}^{-1}\right)$ & 103.3 & 120.2 & 89.2 & 101.8 & 112.7 & 110.6 & 10.1 & 0.623 & 0.205 & 0.408 \\
\hline $\mathrm{T} 3\left(\mathrm{ng} \mathrm{mL} \mathrm{m}^{-1}\right)$ & 1.65 & 1.58 & 1.29 & 1.77 & 1.63 & 1.48 & 0.123 & 0.248 & 0.057 & 0.870 \\
\hline $\mathrm{T} 4\left(\mu \mathrm{g} \mathrm{dL} \mathrm{L}^{-1}\right)$ & 7.10 & 7.77 & 7.63 & 9.65 & 9.44 & 11.11 & 0.731 & $<0.001$ & 0.439 & 0.522 \\
\hline Total protein $\left(\mathrm{g} \mathrm{dL}^{-1}\right)$ & 7.82 & 7.75 & 7.51 & 7.75 & 8.02 & 7.78 & 0.224 & 0.392 & 0.619 & 0.639 \\
\hline Albumin $\left(\mathrm{g} \mathrm{dL}^{-1}\right)$ & 3.35 & 3.27 & 3.41 & 3.33 & 3.25 & 3.41 & 0.0780 & 0.862 & 0.205 & 0.994 \\
\hline Globulin $\left(\mathrm{g} \mathrm{dL}^{-1}\right)$ & 4.47 & 4.48 & 4.10 & 4.42 & 4.76 & 4.37 & 0.238 & 0.396 & 0.340 & 0.688 \\
\hline SUN (mg dL $\left.\mathrm{m}^{-1}\right)$ & 13.4 & 13.9 & 15.9 & 15.1 & 17.5 & 18.2 & 1.48 & 0.052 & 0.203 & 0.735 \\
\hline Cholesterol (mg dL $\left.{ }^{-1}\right)$ & 95.2 & 93.5 & 82.4 & 133.1 & 112.4 & 120.6 & 10.8 & 0.004 & 0.490 & 0.634 \\
\hline Triacylglycerol $\left(\mathrm{mg} \mathrm{dL}^{-1}\right)$ & $18.5 \mathrm{a}$ & $18.7 \mathrm{a}$ & $14.7 \mathrm{~b}$ & $19.5 \mathrm{a}$ & $15.6 \mathrm{a}$ & $15.1 \mathrm{~b}$ & 1.45 & 0.638 & 0.039 & 0.271 \\
\hline $\mathrm{HDL}\left(\mathrm{mg} \mathrm{dL} \mathrm{L}^{-1}\right)$ & $55.8 \mathrm{a}$ & $61.7 \mathrm{a}$ & $46.8 \mathrm{~b}$ & $65.6 \mathrm{a}$ & $64.1 \mathrm{a}$ & $55.0 \mathrm{~b}$ & 3.83 & 0.039 & 0.020 & 0.543 \\
\hline $\mathrm{LDL}\left(\mathrm{mg} \mathrm{dL} \mathrm{L}^{-1}\right)$ & 20.4 & 13.1 & 19.2 & 40.9 & 30.5 & 41.5 & 8.82 & 0.010 & 0.488 & 0.962 \\
\hline $\operatorname{VLDL}\left(\mathrm{mg} \mathrm{dL}^{-1}\right)$ & $3.70 \mathrm{a}$ & $3.75 \mathrm{a}$ & $2.94 \mathrm{~b}$ & $3.89 \mathrm{a}$ & $3.13 \mathrm{a}$ & $3.02 \mathrm{~b}$ & 0.290 & 0.638 & 0.039 & 0.271 \\
\hline
\end{tabular}

GC - ground corn with silage diet; WSC - whole shelled corn diet; FR - feed restriction diet; SUN - serum urea nitrogen; HDL - high density lipoproteins; LDL - low-density lipoproteins; VLDL - very low-density lipoproteins.

a,b,c - Different lowercase letters in the same row, within diet, differ at $\mathrm{P}<0.05$ by least squares means. 
bulls presented greater T4, cholesterol, HDL, and LDL concentrations $(\mathrm{P} \leq 0.039)$ than Angus, while insulin $(\mathrm{P}=0.074)$ and SUN $(\mathrm{P}=0.052)$ concentrations tended to be higher in Zebu cattle. No other metabolites differed between treatments.

\section{Discussion}

Blood parameters were not different between bulls fed GC or WSC diets. This may have happened because, despite the lower DM intake of bulls fed the WSC diet compared with animals fed the GC diet, the WSC diet had higher energy and protein levels, and this could result in a similar intake of these two compounds between animals fed both diets, which in turn would not alter the energy and protein metabolism.

Insulin concentration values found in this study were around the range proposed by Kaneko et al. (2008), while glucose concentration was above the range reported by the authors. This could be a result of the high starch concentration in both GC and WSC diets, since increasing the amount of starch in the rumen may increase propionate production and gluconeogenesis (Russell and Gahr, 2000).

Other works have also found no difference in T4 plasma concentration between animals subjected or not to feed restriction, finding greater T3 concentration in animals fed ad libitum diets (Ekpe and Christopherson, 2000; Campanile et al., 2010). According to Reist et al. (2003), the impact of low energy intake in $\mathrm{T} 3$ blood levels is more pronounced and longer lasting than in T4.

Heat stress could be associated to the lower T4 concentration observed in Angus, reflecting the smaller tolerance of Bos taurus taurus to heat when compared with Zebu cattle. Thyroid hormones play an important role in the regulation of thermogenesis (Kahl et al., 2015), and some evidence suggest that thermal exposition acts on the hypothalamic-pituitary axis, reducing the thyroid-stimulating hormone secretion (Rasouli et al., 2004; Kahl et al., 2015), which is responsible to stimulate both synthesis and secretion of thyroid hormones (Kaneko et al., 2008).

Total protein, albumin, and globulin concentrations were similar to those described by other authors (Gandra et al., 2011; Egea et al., 2015). This similar serum protein levels between ad libitum-fed and limited-fed animals could indicate that even under feed restriction, the bulls had their protein requirements met. In fact, the bulls subjected to feed restriction showed positive nitrogen balance and, as observed in a parallel study by Gomes et al. (2017), they showed positive protein retention. If not required for protein synthesis, amino acids are deaminated by mitochondrial enzymes, and the amino group are transferred into urea for excretion (Kaneko et al., 2008). Then, the greater SUN levels of Nellore bulls suggest differences in protein utilization between the genotypes, indicating that Zebu cattle are less efficient in using absorbed protein (Myer and Elzo, 2010). Despite the difference in the RDP and RUP intake between the diets, the SUN levels were not affected.

The triacylglycerol concentration found in this study was slightly greater than that proposed by Kaneko et al. (2008), while the cholesterol concentration was within the range. The smaller triacylglycerol, HDL, and VLDL concentration in limited-fed animals was probably caused by feed restriction. Other authors also observed smaller concentrations of metabolites related to fat metabolism in animals under feed restriction (Bonnet et al., 2000; Caldeira et al., 2007). In ruminants, after absorption in small intestine, triacylglycerols, along with apolipoproteins, cholesterol, and phospholipids, are packaged into VLDL lipoproteins to deliver long-chain fatty acids to peripheral tissues, and HDL serves to deliver cholesterol to steroidogenic tissues or to membrane synthesis (Drackley, 2000). We did not observe difference in cholesterol levels between animals subjected or not to feed restriction, which is in agreement with other studies (Dashtizadeh et al., 2008; Silva et al., 2015).

Gandra et al. (2011) also observed a greater concentration of lipidogram parameters in Nellore than in taurine cattle, attributing this to the dairy ability of Holstein heifers, in which lipid metabolism is directed to the formation of the mammary gland and milk yield, differently from what happens to beef cattle, in which the lipidogram constituents are deposited in the carcass and are not secreted in the milk. However, both Angus and Nellore are beef breeds. Then, the difference found in this study could be the effect of the greater fat deposition in the muscle of Angus, which is supported by the results

R. Bras. Zootec., 48:e20180172, 2019 
of Martins et al. (2015), who reported slightly enhanced adipogenesis in the longissimus muscle of Angus bulls, and Ladeira et al. (2016), who observed greater gene expression of PPAR $\gamma$ and SREBF1, transcription factors related to lipogenesis, in Angus than in Nellore cattle.

\section{Conclusions}

This study demonstrated that feeding beef cattle for fattening with no-roughage diets does not alter their blood parameters. Furthermore, Nellore have greater lipidogram parameters and serum urea nitrogen levels, which indicate that Zebu cattle may have lower serum removal of nutrients due to a lower demand for fat and protein deposition than Angus bulls.

\section{Conflict of Interest}

The authors declare no conflict of interest.

\section{Author Contributions}

Conceptualization: M.M. Ladeira and M.L. Chizzotti. Data curation: R.A. Gomes and T.S. Martins. Formal analysis: T.S. Martins. Funding acquisition: L.N. Rennó, M.M. Ladeira and M.L. Chizzotti. Investigation: L.N. Rennó, R.A. Gomes, T.S. Martins, K.C. Busato, M.M. Ladeira, M.H. Oliveira, J.M. Silva Júnior and M.L. Chizzotti. Methodology: L.N. Rennó, R.A. Gomes, T.S. Martins, M.M. Ladeira and M.L. Chizzotti. Project administration: L.N. Rennó, R.A. Gomes, M.M. Ladeira and M.L. Chizzotti. Resources: R.A. Gomes, M.M. Ladeira and M.L. Chizzotti. Supervision: M.M. Ladeira and M.L. Chizzotti. Validation: L.N. Rennó, R.A. Gomes and T.S. Martins. Visualization: L.N. Rennó, R.A. Gomes and T.S. Martins. Writing-original draft: L.N. Rennó, R.A. Gomes, T.S. Martins and K.C. Busato. Writing-review \& editing: L.N. Rennó, R.A. Gomes, T.S. Martins and K.C. Busato.

\section{Acknowledgments}

This work was supported by grants from Conselho Nacional de Desenvolvimento Científico e Tecnológico (CNPq; \#477399/2012-6) and Fundação de Amparo à Pesquisa do Estado de Minas Gerais (FAPEMIG; \#CVZ-APQ-04752-10).

\section{References}

Bonnet, M.; Leroux, C.; Faulconnier, Y.; Hocquette, J. F.; Bocquier, F.; Martin, P. and Chilliard, Y. 2000. Lipoprotein lipase activity and mRNA are up-regulated by refeeding in adipose tissue and cardiac muscle of sheep. The Journal of Nutrition 130:749-756. https://doi.org/10.1093/jn/130.4.749

Caldeira, R. M.; Belo, A. T.; Santos, C. C.; Vazques, M. I. and Portugal, A. V. 2007. The effect of long-term feed restriction and over-nutrition on body condition score, blood metabolites and hormonal profiles in ewes. Small Ruminant Research 68:242-255. https://doi.org/10.1016/j.smallrumres.2005.08.026

Campanile, G.; Baruselli, P. S.; Vecchio, D.; Prandi, A.; Neglia, G.; Carvalho, N. A. T.; Sales, J. N. S.; Gasparrini, B. and D’Occhio, M. J. 2010. Growth, metabolic status and ovarian function in buffalo (Bubalus bubalis) heifers fed a low energy or high energy diet. Animal Reproduction Science 122:74-81. https://doi.org/10.1016/j.anireprosci.2010.07.005

Carvalho, J. R. R.; Chizzotti, M. L.; Schoonmaker, J. P.; Teixeira, P. D.; Lopes, R. C.; Oliveira, C. V. R. and Ladeira, M. M. 2016. Performance, carcass characteristics and ruminal $\mathrm{pH}$ of Nellore and Angus young bulls fed a whole shelled corn diet. Journal of Animal Science 94:2451-2459. https://doi.org/10.2527/jas.2015-0162

Dashtizadeh, M.; Zamiri, M. J.; Kamalzadeh, A. and Kamali, A. 2008. Effect of feed restriction on compensatory growth response of young male goats. Iranian Journal of Veterinary Research 9:109-120. https://doi.org/10.22099/IJVR.2008.532

Drackley, J. K. 2000. Lipid metabolism. p.97-120. In: Farm animal metabolism and nutrition. D’Mello, J. P. F., ed. CABI Publishing, New York.

Egea, M.; Linares, M. B.; Hernández, F.; Madrid, J. and Garrido, M. D. 2015. Pre-slaughter administration of glycerol as carbohydrate precursor and osmotic agent to improve carcass and beef quality. Livestock Science 182:1-7. https://doi. org/10.1016/j.livsci.2015.10.011 
Ekpe, E. D. and Christopherson, R. J. 2000. Metabolic and endocrine responses to cold and feed restriction in ruminants. Canadian Journal of Animal Science 80:87-95. https://doi.org/10.4141/A99-028

Friedewald, W. T.; Levy, R. I. and Fredrickson, D. S. 1972. Estimation of the concentration of low-density lipoprotein cholesterol in plasma, without use of the preparative ultracentrifuge. Clinical Chemistry 18:499-502.

Gandra, J. R.; Freitas Jr., J. E.; Barleta, R. V.; Maturama Filho, M.; Gimenes, L. U.; Vilela, F. G.; Baruselli, P. S. and Rennó, F. P. 2011. Productive performance, nutrient digestion and metabolism of Holstein (Bos taurus) and Nellore (Bos taurus indicus) cattle and Mediterranean Buffaloes (Bubalus bubalis) fed with corn-silage based diets. Livestock Science 140:283-291. https://doi.org/10.1016/j.livsci.2011.04.005

Gomes, R. A.; Busato, K. C.; Ladeira, M. M.;Johnson, K. A.; Galvão, M. C.; Rodrigues, A. C. and Chizzotti, M. L. 2017. Energy and protein requirements for Angus and Nellore young bulls. Livestock Science 195:67-73. https://doi.org/10.1016/j.livsci.2016.11.011

Kahl, S.; Elsasser, T. H.; Rhoads, R. P.; Collier, R. J. and Baumgard, L. H. 2015. Environmental heat stress modulates thyroid status and its response to repeated endotoxin challenge in steers. Domestic Animal Endocrinology 52:43-50. https://doi.org/10.1016/j.domaniend.2015.02.001

Kaneko, J. J.; Harvey, J. W. and Bruss, M. L. 2008. Clinical Biochemistry of Domestic Animals. 6th ed. Academic Press, San Diego.

Krehbiel, C. R.; Kreikemeier, K. K. and Ferrell, C. L. 2000. Influence of Bos indicus crossbreeding and cattle age on apparent utilization of a high-grain diet. Journal of Animal Science 78:1641-1647. https://doi.org/10.2527/2000.7861641x

Ladeira, M. M.; Teixeira, P. D.; Gionbelli, M. P.; Chizzotti, M. L.; Carvalho, J. R. R.; Oliveira, D. M. and Coelho, T. C. 2016. Chemical composition and expression of genes involved in lipid metabolism in the muscle of Nellore and Angus young bulls fed whole shelled corn diet. Journal of Animal Science 94(suppl. 5):422-423. https://doi.org/10.2527/jam2016-0878

Loftus, R. T.; MacHugh, D. E.; Bradrey, D. G.; Sharp, P. M. and Cunnigham, P. 1994. Evidence for two independent domestications of cattle. Proceedings of the National Academy of Sciences of United States of America 91:2757-2761. https://doi.org/10.1073/pnas.91.7.2757

Martins, T. S.; Sanglard, L. M. P.; Silva, W.; Chizzotti, M. L.; Rennó, L. N.; Serão, N. V. L.; Silva, F. F.; Guimarães, S. E. F.; Ladeira, M. M.; Dodson, M. V.; Du, M. and Duarte, M. S. 2015. Molecular factors underlying the deposition of intramuscular fat and collagen in skeletal muscle of Nellore and Angus cattle. PLoS One 10:e0139943. https://doi.org/10.1371/journal.pone.0139943

Myer, R. O. and Elzo, M. A. 2010. Effect of residual feed intake, gender and breed composition on blood urea nitrogen concentration in an Angus-Brahman multi-breed herd. In: ADSA-PSA-AMPA-CSAS-ASAS Joint Annual Meeting, Denver.

NRC - National Research Council. 2000. Nutrient requirements of beef cattle. 6th ed. National Academy Press, Washington, DC.

NRC - National Research Council. 2001. Nutrient requirements of dairy cattle. National Academy Press, Washington, DC.

Rasouli, A.; Nouri, M.; Khajeh, G. H. and Rasekh, A. 2004. The influences of seasonal variations on thyroid activity and some biochemical parameters of cattle. Iranian Journal of Veterinary Research 5:55-62.

Reist, M.; Erdin, D.; von Euw, D.; Tschuemperlin, K.; Leuenberger, H.; Delavaud, C.; Chilliard, Y.; Hammon, H. M.; Kuenzi, N. and Blum, J. W. 2003. Concentrate feeding strategy in lactating dairy cows: metabolic and endocrine changes with emphasis on leptin. Journal of Dairy Science 86:1690-1706. https://doi.org/10.3168/jds.S0022-0302(03)73755-2

Russell, R. W. and Gahr, S. A. 2000. Glucose availability and associated metabolism. p.121-148. In: Farm animal metabolism and nutrition. D’Mello, J. P. F., ed. CABI Publishing, New York.

Silva, N. C. D.; Teixeira, I. A. M. A.; Härter, C. J.; Figueiredo, F. O. M.; Leite, R. F.; Freire, M. M. and Resende, K. T. 2015. Female goat kids change their energy metabolism when subjected to feed restriction. In: ADSA-ASAS Joint Annual Meeting, Orlando.

Traxler, M. J.; Fox, D. G.; Perry, T. C.; Dickerson, R. L. and Williams, D. L. 1995. Influence of roughage and grain processing in high-concentrate diets on the performance of long-fed Holstein steers. Journal of Animal Science 73:1888-1900. https://doi.org/10.2527/1995.7371888x

Turgeon, O. A.; Szasz, J. I.; Koers, W. C.; Davis, M. S. and Vander Pol, K. J. 2010. Manipulating grain processing method and roughage level to improve feed efficiency in feedlot cattle. Journal of Animal Science 88:284-295. https://doi. org/10.2527/jas.2009-1859

Turner, J. W. 1980. Genetic and biological aspects of Zebu adaptability. Journal of Animal Science 50:1201-1205. https://doi.org/10.2527/jas1980.5061201x 